\title{
Prostaglandin F-2 $\alpha$ causes regression of an hCG-induced corpus luteum before Day 5 of its lifespan in cattle*
}

\author{
H. J. Howard $\dagger$ and J. H. Britt \\ Department of Animal Science, North Carolina State University, Raleigh, \\ North Carolina 27695-7621, USA
}

\begin{abstract}
Summary. The experimental objective was to evaluate how a spontaneously formed corpus luteum (CL) differed in its response to prostaglandin (PG) F-2 $\alpha$, given during the first 5 days after ovulation, from a CL induced during dioestrus with hCG. Sixteen Holstein heifers were used during each of 2 consecutive oestrous cycles. During the first cycle (sham cycle), heifers were given no PGF- $2 \alpha$ (control) or PGF- $2 \alpha$ ( $25 \mathrm{mg}$, i.m.) on Day 2, 4 or 6 (oestrus = Day 0 ). During the second cycle (hCG-treated cycle), heifers were given hCG (5000 i.u., i.m.) on Day 10, followed by no PGF-2 $\alpha$ (control) or PGF-2 $\alpha$ on Day 12, 14 or 16, corresponding to 2,4 or 6 days after the ovulatory dose of hCG. A new ovulation was induced in 13 of 16 heifers given hCG on Day 10. Luteolysis did not occur immediately in heifers given PGF- $2 \alpha$ on Day 2 or 4 during the sham cycle, but concentration of progesterone in serum during the remainder of the cycle was lower in heifers given PGF- $2 \alpha$ on Day 4 than in sham controls or heifers given PGF- $2 \alpha$ on Day $2(P<0.05)$. Luteolysis occurred immediately in heifers given PGF-2 $\alpha$ on Day 6 of the sham cycle or on Day 12,14 or 16 of the hCG-treated cycle, with concentration of progesterone in serum decreasing to $<1 \mathrm{ng} / \mathrm{ml}$ within 2 days. Intervals between periods of oestrus were shorter in heifers given PGF-2 $\alpha$ on Day 6 of the sham cycle $(8.3 \pm 0.3$ days $)$ than in control heifers $(20.5 \pm 0.9$ days) or those given PGF- $2 \alpha$ on Day 2 or $4(20.8 \pm 0.6$ and $18.4 \pm 0.5$ days; $P<0.05)$ of the sham cycle. During the hCG-treated cycle, interoestrous intervals were shorter in heifers given PGF- $2 \alpha$ on Day 12,14 or $16(19.5 \pm 0.5,18.8 \pm 0.5$ and $20.8 \pm 1.3$ days $)$ than those of hCG-treated controls $(25.5 \pm 1.8$ days; $P<0.05)$. It was concluded that $C L$ induced by treatment with hCG on Day 10 of the oestrous cycle regress after exogenous PGF-2 $\alpha$ given within 2 days after ovulation, whereas spontaneously formed CL respond to PGF- $2 \alpha$ only after Day 5.
\end{abstract}

Keywords: cattle; progesterone; gonadotrophin; corpus luteum; prostaglandin F-2a

\section{Introduction}

Since Pharriss \& Wyngarden (1969) first demonstrated that prostaglandin (PG) F-2 $\alpha$ caused luteolysis in pseudopregnant rats, substantial research in ruminants has focussed on the luteolytic role of PGF-2 $\alpha$ (McCracken et al., 1984; Niswender et al., 1985), and on the applications of PGF- $2 \alpha$ for regulation of the oestrous cycle. Intrauterine or intramuscular administration of PGF- $2 \alpha$ between Day 5 and 16 of a cow's oestrous cycle causes corpus luteum (CL) regression (Lauderdale, 1972; Rowson et al., 1972; Hafs et al., 1974). Cattle treated early in the luteal phase (Days 5 to 8 ) have shorter intervals from treatment to oestrus than those treated during Days 12 to

*Reprint requests to Dr J. H. Britt.

$\nmid$ Present address: Reproduction Research Unit, USDA-ARS, Meat Animal Research Center, P.O. Box 166, Clay Center, NE 68933, USA. 
15 (Refsal \& Seguin, 1980; King et al., 1982; Stevenson et al., 1984; Watts \& Fuquay, 1985). Such variability prevents successful use of timed artificial insemination after treatment with PGF-2 $\alpha$.

To understand what makes the CL non-responsive to PGF- $2 \alpha$ during the first few days after ovulation and what affects the interval from luteolysis to oestrus during responsive stages of the cycle, we have focussed on luteal function in cows treated with human chorionic gonadotrophin (hCG) on Day 10 of the oestrous cycle (Scott \& Britt, 1986). Midcycle treatment with hCG induces an ovulation and formation of a second CL (Schomberg et al., 1967; Price \& Webb, 1989), and extends the cycle by about 5 days (Seguin et al., 1977; Eduvie \& Seguin, 1982). Scott \& Britt (1986) noted that cows given hCG on Day 10 responded with luteolysis when given $25 \mathrm{mg}$ PGF- $2 \alpha$ on Day 15, and that both the original and hCG-induced CL regressed. Based on these results, we speculated that hCG-induced CL might regress in response to PGF-2 $\alpha$ given earlier in their lifespan. Therefore, the objective of the present study was to determine whether hCG-induced CL would regress in response to exogenous PGF-2 $\alpha$ before Day 5 after ovulation.

\title{
Materials and Methods
}

\begin{abstract}
Animals. Oestrous cycles of 16 Holstein heifers were synchronized by giving two injections of PGF-2 $\alpha$ (Lutalyse, Upjohn Co., Kalamazoo, MI, USA: $25 \mathrm{mg}$, i.m.), 11 days apart. The ensuing oestrous cycle was termed the sham cycle, and heifers were given no PGF-2 $\alpha$ (control), or PGF-2 $\alpha(25 \mathrm{mg}$, i.m.) on Day 2,4 or 6 of that cycle $(\mathrm{N}=4$ per group, Day $0=$ oestrus). During the next cycle, termed the hCG-treated cycle, heifers were given hCG (5000 i.u., i.m.) on Day 10, followed by no PGF-2 $\alpha$ (control), or PGF-2 $\alpha$ on Day 12, 14 or 16 of the cycle. Treatments with PGF-2 $\alpha$ were randomized among heifers during both the sham cycle and hCG-treated cycle. Days 12, 14 and 16 of the hCGtreated cycle corresponded to 2,4 and 6 days after the ovulatory dose of $\mathrm{hCG}$ and were chosen to mimic the timing in the sham cycle when PGF- $\alpha$ was given 2, 4 or 6 days after the presumed preovulatory surge of LH. It is well established that the LH surge occurs from -8 to $+8 \mathrm{~h}$ of the onset of oestrus (Maurer \& Echternkamp, 1982; Bernard et al., 1983; Helmer \& Britt, 1987), and ovulation occurs 20-30 h after the onset of oestrus (Bernard et al., 1983). Based on changes in serum oestradiol (H. J. Howard, R. G. Scott \& J. H. Britt, unpublished data) and rectal palpation (H. J. Howard \& J. H. Britt, unpublished data) after hCG on Day 10, ovulation appears to occur about $24 \mathrm{~h}$ after treatment. Thus, by giving PGF-2 $\alpha$ on Day 2, 4 and 6 of the sham cycle or Day 12, 14 and 16 of the hCG-treated cycle, the spontaneously formed and hCG-induced CL were exposed to PGF-2 $\alpha$ at comparable ages. During the hCGtreated cycle, the ovaries of the heifers were examined by transrectal palpation before Day 10 to identify the original CL. The ovaries of each heifer were palpated once 2-6 days after hCG, but before PGF-2 $\alpha$, for identification of a new $\mathrm{CL}$ or ovulation depression. Heifers were housed in a free stall barn and allowed access to an outside dirt lot. They were fed a complete mixed ration of maize silage and grain concentrate twice daily, and water and alfalfa/grass mixed hay were available on a free choice basis. Heifers were observed for oestrus for $30 \mathrm{~min}$ twice daily (07:00 and 17:00 h).
\end{abstract}

Blood sampling and assays. Beginning on the day of oestrus, blood samples were collected on alternate days of each oestrous cycle. Sampling frequency was increased to once daily during 4 days after PGF- $2 \alpha$ or 4 days before next expected oestrus. Blood from a coccygeal vein was collected into vacuum tubes, placed on ice and transported to the laboratory, where it was stored at $4^{\circ} \mathrm{C}$ for $12 \mathrm{~h}$. Serum was collected by centrifugation at $2400 \mathrm{~g}$ for $30 \mathrm{~min}$, and was frozen at $-20^{\circ} \mathrm{C}$ until assay for progesterone and oestradiol.

The concentration of progesterone in serum was determined by procedures validated in this laboratory by Stevenson et al. (1981). The intra-assay and interassay coefficients of variation for 4 assays were 7.6 and $8.9 \%$, respectively, and the sensitivity of the assay was $0.20 \mathrm{ng} / \mathrm{ml}$.

Concentration of oestradiol-17 $\beta$ in serum was determined using a specific antiserum provided through the courtesy of N. R. Mason (Mason \& March, 1975). Cross-reactivity data for this antiserum have been published previously (Frank et al., 1983; Cox et al., 1987). The assay procedures were as validated by Cox et al. (1987), with the following modifications. First, serum in $0.2 \mathrm{ml}$ samples was extracted with $2 \mathrm{ml}$ ethyl acetate. Second, the dilution of antiserum was 1:1.5 $\times 10^{6}$, and $0.2 \mathrm{ml}$ was added to each assay tube. Third, radiolabelled oestradiol (oestradiol-6-(Ocarboxymethyl)oximino-2-[125I]iodohistamine) was used as the ligand at 8000 c.p.m. per assay tube. Finally, after standards and unknowns were incubated at $4^{\circ} \mathrm{C}$ for $16-24 \mathrm{~h}$ with antiserum, radiolabelled oestradiol was added and incubated for an additional $6 \mathrm{~h}$, before separation of bound and free hormone as previously described (Cox $e t$ al., 1987). This dilution of antiserum bound approximately $50 \%$ of the radiolabelled oestradiol. Extracts of serum that had oestradiol added at concentrations of $5-80 \mathrm{pg} / \mathrm{ml}$ displaced bound radiolabelled oestradiol in a fashion parallel to the standard curve, and had a correlation of 0.987 with oestradiol standards in assay buffer. Extraction efficiency of radiolabelled oestradiol from serum averaged $87 \pm 2 \%$. Intra-assay and interassay coefficients of variation for 2 assays were 9.4 and $9.2 \%$, respectively, and the sensitivity of the assay was $1.0 \mathrm{pg} / \mathrm{ml}$.

Statistical analyses. Data were analysed by least squares analysis of variance using General Linear Models of the Statistical Analysis System (Spector et al., 1985). For the overall analysis there were 8 treatment classes, 4 from the sham cycle (control, and PGF- $2 \alpha$ on Day 2, 4 or 6), and 4 from the hCG-treated cycle (control, and PGF-2 $\alpha$ on Day 
12, 14 or 16). Data that included only one observation per animal were analysed with treatment as the only source of variation in the model. Models for data that included repeated measurements of hormones utilized treatment, heifer within treatment, repeated sample, and the interaction between treatment and repeated sample as sources of variation. The heifer within treatment mean square was used as the error term to test the effects of treatment. To characterize luteolysis in heifers given PGF-2 $\alpha$, data included progesterone values from the day of PGF-2 $\alpha$ to 4 days after PGF-2 $\alpha$, inclusive. A similar strategy was used to assess changes in progesterone from Day 10 to 15 and Day 15 to 20 in control heifers of both cycles; this was done to evaluate effects of hCG irrespective of PGF-2 $\alpha$ treatment. For statistical analyses of concentration of oestradiol in serum, data from 8 days before oestrus, through the day of oestrus were used.

\section{Results}

A newly formed CL or ovulation depression was detected in 13 of 16 heifers given 5000 i.u. hCG on Day 10 of the oestrous cycle, and 9 of the 13 newly formed CL were detected on the ovary contralateral to the original CL. Of the 3 heifers without evidence of an induced ovulation, one was in the control group, one received PGF-2 $\alpha$ on Day 14 and one on Day 16. The control heifer had an interoestrous interval of 26.5 days.

Treatment with hCG extended the cycle 5 days $(P<0.05$, Table 1$)$. During the sham cycle, only heifers given PGF- $2 \alpha$ on Day 6 exhibited shortened oestrous cycles $(P<0.05)$; all 4 heifers treated on Day 6 returned to oestrus within 2-3 days. Heifers given PGF- $2 \alpha$ on Day 4 of the sham cycle tended $(P=0.12)$ to have shorter oestrous cycles than control heifers or heifers given PGF-2 $\alpha$ on Day 2. During the hCG-treated cycle, all heifers that received PGF- $2 \alpha$ had cycles of similar duration, and their cycles were shorter than those of the control heifers $(P<0.05$, Table 1$)$.

Table 1. Duration of oestrous cycle and interval from PGF-2 $\alpha$ or luteolysis to oestrus in heifers (4/group) given PGF-2 $\alpha$ during sham or hCG-treated cycles

\begin{tabular}{|c|c|c|c|}
\hline \multirow[b]{2}{*}{ Treatment } & \multirow[b]{2}{*}{$\begin{array}{l}\text { Oestrous cycle } \\
\text { duration (days) }\end{array}$} & \multicolumn{2}{|c|}{ Interval (days) from: } \\
\hline & & $\begin{array}{c}\text { PGF-2 } \alpha \text { to } \\
\text { oestrus (days) }\end{array}$ & $\begin{array}{l}\text { Luteolysis* to } \\
\text { oestrus (days) }\end{array}$ \\
\hline \multicolumn{4}{|l|}{ Sham cycle } \\
\hline Control & $20 \cdot 5 \pm 0 \cdot 9^{a}$ & - & $2 \cdot 0 \pm 0 \cdot 7^{\mathrm{a}}$ \\
\hline PGF- $2 \alpha$, Day 2 & $20.8 \pm 0.6$ & $18 \cdot 8 \pm 0.6^{a}$ & $1.8 \pm 0.4^{2}$ \\
\hline PGF- $2 \alpha$, Day 4 & $18.4 \pm 0.5^{a}$ & $14.4 \pm 0.5^{b}$ & $1 \cdot 2 \pm 0 \cdot 3^{a}$ \\
\hline PGF-2 $\alpha$, Day 6 & $8 \cdot 3 \pm 0 \cdot 3^{b}$ & $2 \cdot 3 \pm 0.3^{c}$ & $1 \cdot 3 \pm 0 \cdot 3^{\mathrm{a}}$ \\
\hline \multicolumn{4}{|l|}{ hCG-treated cycle } \\
\hline Control & $25 \cdot 5 \pm 1 \cdot 8^{c}$ & - & $4 \cdot 8 \pm 1 \cdot 4^{b c}$ \\
\hline PGF-2 $\alpha$, Day 12 & $19 \cdot 5 \pm 0 \cdot 5^{a}$ & $7 \cdot 5 \pm 0 \cdot 5^{d}$ & $5 \cdot 8 \pm 0 \cdot 3^{c}$ \\
\hline PGF-2a, Day 14 & $18.8 \pm 0.5^{\mathrm{a}}$ & $4.8 \pm 0.5^{e}$ & $2 \cdot 3 \pm 0.6^{\mathrm{ab}}$ \\
\hline PGF-2 $\alpha$, Day 16 & $20 \cdot 8 \pm 1 \cdot 3^{a}$ & $4 \cdot 8 \pm 1 \cdot 3^{\mathrm{e}}$ & $3 \cdot 5 \pm 1 \cdot 4^{\mathrm{abc}}$ \\
\hline
\end{tabular}

Values are least squares mean \pm s.e.

*Luteolysis was defined as complete when serum progesterone concentration had decreased by at least $80 \%$ from its previous maximum value in controls of both cycles or in heifers given PGF- $2 \alpha$ on Days 2 or 4 of the sham cycle, or by $80 \%$ from the time of PGF-2 $\alpha$ in heifers given PGF-2 $\alpha$ on Day 6 of the sham cycle, or on Day 12, 14 or 16 of the hCG cycle.

${ }^{\text {abede }}$ Means within a column with different letters differ $(P<0.05)$.

Progesterone increased $43 \%$ from $7.5 \pm 0.8 \mathrm{ng} / \mathrm{ml}$ on Day 10 to $10 \cdot 7 \pm 1.9 \mathrm{ng} / \mathrm{ml}$ on Day 16 in control heifers of the sham cycle (Fig. 1a). Progesterone increased $112 \%$ from $8 \cdot 3 \pm 0 \cdot 6$ to $17.6 \pm 1.7 \mathrm{ng} / \mathrm{ml}$ during the corresponding period in control heifers of the hCG-treated cycle $(P<0.05 ;$ Fig. 1b). In the single control heifer in which no new ovulation depression or CL was detected after hCG, progesterone increased from 11 to $22 \mathrm{ng} / \mathrm{ml}$ between Days 10 and 16. During the sham cycle, control heifers and heifers given PGF- $2 \alpha$ on Day 2 had similar progesterone 
profiles (Fig. 1a). Heifers given PGF-2 $\alpha$ on Day 4 had lower $(P<0.05)$ serum progesterone values on Day 4 through Day 16 than did control heifers and heifers given PGF-2 $\alpha$ on Day 2, whereas progesterone was similar among these groups from Day 16 through subsequent oestrus (Fig. 1a). Progesterone concentrations declined immediately in heifers given PGF-2 $\alpha$ on Day 6 of the sham cycle, reaching $<1 \mathrm{ng} / \mathrm{ml}$ within $24 \mathrm{~h}$ (Fig. 1a).

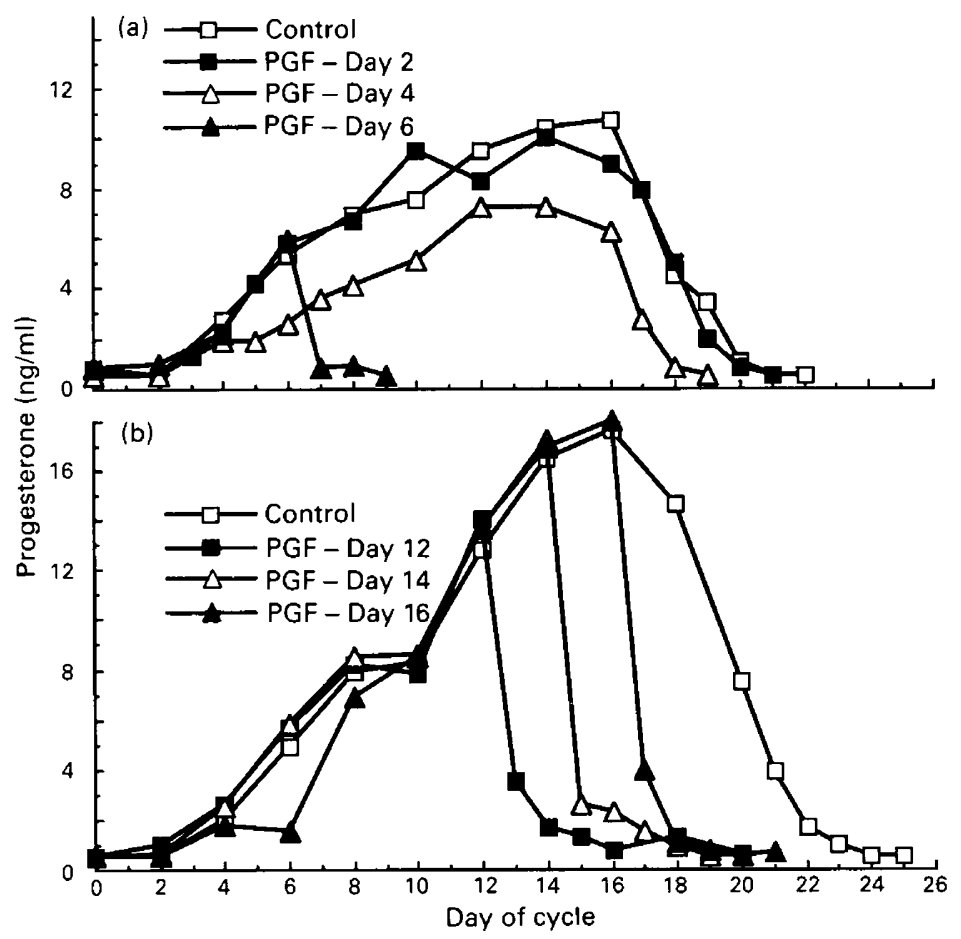

Fig. 1. Concentration of progesterone in serum of heifers during the sham and hCG-treated cycle. During the sham cycle (a), heifers were given no PGF-2 $\alpha$ ( $\square$ ) or PGF-2 $\alpha$ on Day $2(\boldsymbol{D})$, Day $4(\triangle)$ or Day 6 $(\Delta)$, and during the hCG-treated cycle (b), heifers were given hCG on Day 10 , followed by no PGF-2 $\alpha(\square)$ or PGF-2 $\alpha$ on Day $12(\boldsymbol{Q})$, Day $14(\triangle)$ or Day $16(\Delta)$. The pooled s.e. was $0.4 \mathrm{ng} / \mathrm{ml}$.

Progesterone declined immediately after treatment with PGF-2 $\alpha$ on Day 12,14 or 16 of the hCG cycle, decreasing to $<2 \mathrm{ng} / \mathrm{ml}$ within $48 \mathrm{~h}$, and to $<1 \mathrm{ng} / \mathrm{ml}$ within $72 \mathrm{~h}$ (Fig. $1 \mathrm{~b}$ ). The rate of decline in progesterone varied among the heifers given PGF-2 $\alpha$ on Day 12 and 14; therefore, examples of individual profiles are presented in Fig. 2. Progesterone profiles of 3 of 4 heifers of each group indicated that complete luteolysis occurred after PGF-2 $\alpha$ on Day 12 (No. 58) or Day 14 (No. 36). One heifer given PGF-2 $\alpha$ on Day 12 (No. 51) and one given PGF-2 $\alpha$ on Day 14 (No. 53) showed an immediate decrease in progesterone, but then progesterone plateaued at $2-3 \mathrm{ng} / \mathrm{ml}$ for 4-5 days, suggesting that complete luteolysis had not occurred. Overall, the decrease in progesterone after PGF-2 $\alpha$ was similar among heifers given PGF-2 $\alpha$ on Day 12, 14 or 16 of the hCG-treated cycle or on Day 6 of the sham cycle.

Intervals from PGF-2 $\alpha$ to oestrus and luteolysis to oestrus are shown in Table 1. Heifers given PGF- $2 \alpha$ on Day 2 or 4 of the control cycle did not undergo luteolysis in response to PGF-2 $\alpha$, therefore interval from PGF-2 $\alpha$ to oestrus was longer than in the other PGF-2 $\alpha$-treated groups in both cycles. Heifers given PGF-2 $\alpha$ on Day 6 of the sham cycle had shorter intervals from PGF-2 $\alpha$ to oestrus than did heifers given PGF-2 $\alpha$ on Day 12,14 or 16 of the hCG-treated cycle $(P<0.05)$. 


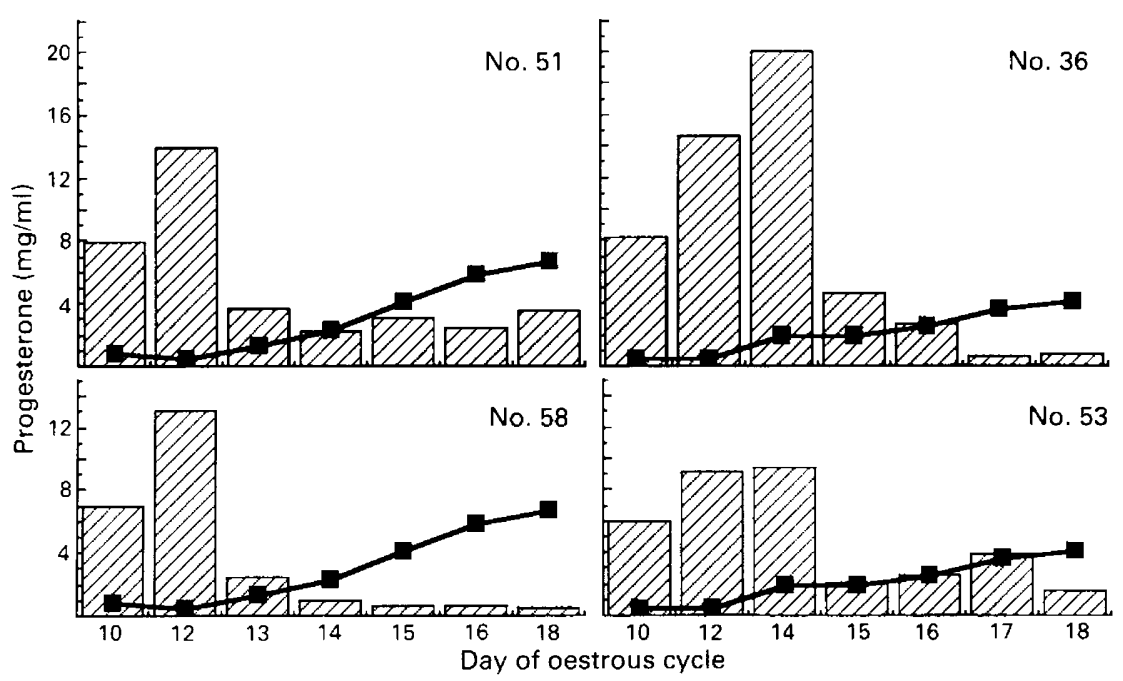

Fig. 2. Profiles of serum progesterone $(\mathrm{ng} / \mathrm{ml})$ for individual heifers treated with hCG on Day 10 and PGF- $2 \alpha$ on Day 12 or 14. The vertical bars represent progesterone during Days 10-18 of the hCG cycle. For comparison, the solid line represents the mean progesterone during Days $0-8$ of the sham cycle for heifers given PGF- $2 \alpha$ on Day 2 or 4. Complete luteolysis occurred in 3 of 4 heifers of each group after PGF-2 $\alpha$ on Day 12 or 14 as illustrated by Nos 58 and 36, respectively. Incomplete luteolysis occurred in 1 heifer each treated with PGF-2 $\alpha$ on Day 12 (No. 51) or Day 14 (No. 53).

Luteolysis was defined as complete when progesterone had fallen by at least $80 \%$ of the previous maximum value for control heifers in each cycle, or by $80 \%$ from the time of PGF- $2 \alpha$ treatment in heifers that underwent luteal regression after PGF-2 $\alpha$. Over all treatments the interval from luteolysis to oestrus was longer during the hCG-treated cycle $(4 \cdot 1 \pm 0.4$ days) than the sham cycle ( $1.6 \pm 0.5$ days $)$.

The concentration of oestradiol in serum is illustrated in Fig. 3. Since there was such variability in interval from PGF- $2 \alpha$ to oestrus in hCG-treated heifers the data were normalized around oestrus to characterize changes in oestradiol once follicular development began. The rise in oestradiol before oestrus was similar among all treatments over both cycles.

\section{Discussion}

The results of this study show that $\mathrm{CL}$ formed after treatment with hCG during midcycle underwent luteolysis in response to PGF-2 $\alpha$ during the first 5 days after ovulation. Spontaneously formed CL of the sham cycle were unresponsive to PGF- $2 \alpha$ at similar ages, as previously reported (Lauderdale, 1972; Rowson et al., 1972; Hafs et al., 1974). Heifers given PGF-2 $\alpha$ on Day 6 of the sham cycle experienced immediate luteolysis with progesterone falling to $<1 \mathrm{ng} / \mathrm{ml}$ in $24 \mathrm{~h}$, and all heifers in this group exhibited oestrus in 2 or 3 days, a typical response to PGF- $2 \alpha$ injection between Days 5 and 16 of the cycle.

The reason why CL newly formed in response to $\mathrm{hCG}$ underwent regression after exogenous PGF- $2 \alpha$ remains unclear, but might be related to the cell types of the induced CL. The CL of ruminants comprises 2 major steroidogenic cell types, large and small luteal cells (Donaldson \& Hansel, 1965; Priedkalns et al., 1968; Alila \& Hansel, 1984). Responsiveness to, and binding of, PGF-2 $\alpha$ reside mainly in large luteal cells of sheep, whereas the response to and binding of LH or hCG occur primarily in small luteal cells (Fitz et al., 1982, 1984a, b). Transition from early to late dioestrus is accompanied by an increase in the ratio of large to small luteal cells, as small luteal cells 


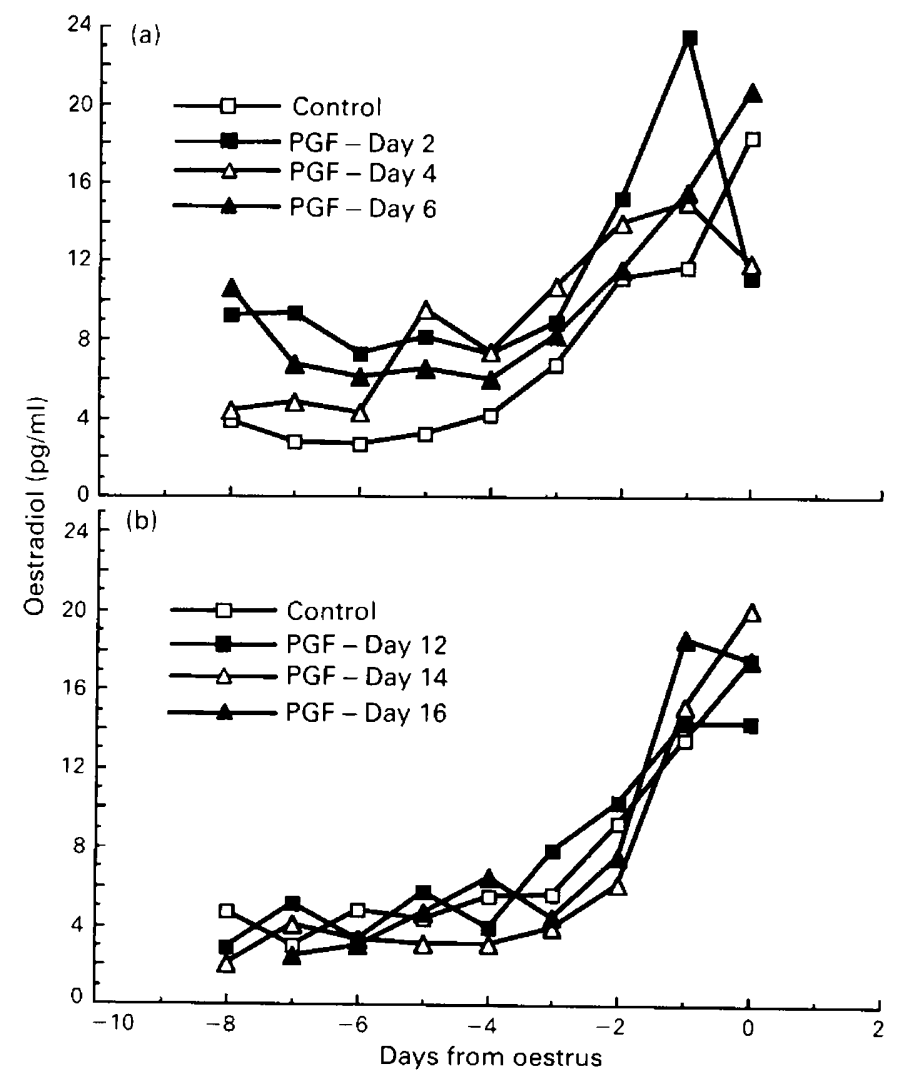

Fig. 3. Concentration of oestradiol in serum of heifers during the sham and hCG-treated cycle. During the sham cycle (a) heifers were given no PGF-2 $\alpha$ ( $\square$ ) or PGF-2 $\alpha$ on Day 2 (ם), Day 4 $(\triangle)$ or Day $6(\Delta)$, and during the hCG cycle (b), heifers were given hCG on Day 10, followed by no PGF-2 $\alpha(\square)$ or PGF-2 $\alpha$ on Day $12(\boldsymbol{\square})$, Day $14(\triangle)$ or Day $16(\Delta)$. The pooled s.e. was $0.5 \mathrm{pg} / \mathrm{ml}$.

differentiate into large cells during the course of the oestrous cycle (Alila \& Hansel, 1984). Treatment of sheep with 300 i.u. hCG on both Day 5 and 7.5 of the cycle increased the ratio of large to small luteal cells in CL collected on Day 10 of the oestrous cycle (Farin et al., 1988). Such an effect of hCG on luteal cell populations in the present study might explain how hCG-induced CL regress in response to exogenous PGF- $2 \alpha$ sooner after ovulation than do spontaneously formed CL.

Midcycle follicles have the ability to ovulate and form CL of normal lifespan when cattle are synchronized with agents such as PGF-2 $\alpha$. Therefore, the fact that hCG-induced CL arise from follicles that are not destined to ovulate spontaneously is not likely to explain why they behave differently in response to PGF-2a per se. Battista et al. (1984) and Garrett et al. (1988) showed that, when spontaneously formed $\mathrm{CL}$ were exposed to a progestational environment during formation (Days 0-3), oestrous cycles and luteal lifespan were shortened. Thus it is not surprising that hCG-induced CL, formed in the face of high progesterone, regress naturally around Day 18-22 of the cycle (Fig. 1b).

Since hCG-induced $\mathrm{CL}$ are formed under conditions of elevated progesterone, this might explain why they regress after PGF- $2 \alpha$ before the 5 th day afer ovulation. However, CL that formed spontaneously when progesterone was artificially elevated during the first 3 days of the oestrous cycle were not more responsive to the luteolytic effects of PGF-2 $\alpha$ on Day 3 than were CL of cattle 
on Day 3 of a normal cycle (Battista et al., 1984). Thus elevated progesterone before treatment with hCG may not be the reason for increased responsiveness of the induced CL to PGF- $2 \alpha$

Duration of the oestrous cycles and progesterone profiles were similar between sham control heifers and heifers given PGF-2 $\alpha$ on Day 2 of the sham cycle. This indicated that the CL on Day 2 had not developed sufficiently to show a decrease (transient or otherwise) in the secretion of progesterone after PGF-2 $\alpha$. Heifers that were given PGF-2 $\alpha$ on Day 4 of the sham cycle tended to have a shorter interoestrous interval, and had lower concentrations of progesterone in serum through Day 16 of the cycle than did sham control heifers or heifers given PGF-2 $\alpha$ on Day 2. Helmer \& Britt (1987) did not detect a decrease in progesterone after giving heifers three $25 \mathrm{mg}$ injections of PGF-2 $\alpha$ at 12-h intervals from Day 3 to 4 of the cycle, but Beal et al. (1980) reported lower concentrations of progesterone throughout the ensuing cycle if animals were given daily or twice daily $25 \mathrm{mg}$ injections of PGF-2 $\alpha$ during Days 2 to 4 or Days 3 to 4 of the cycle. In the Day2-4 CL, receptors for PGF-2 $\alpha$ may be present in amounts that allow for a transient decrease in progesterone, but do not permit complete luteolysis after exogenous PGF-2 $\alpha$.

Heifers that were given PGF-2 $\alpha$ on Day 12,14 or 16 of the hCG-treated cycle had shorter interoestrous intervals than did hCG control heifers, and progesterone decreased immediately after PGF- $2 \alpha$, falling to $<1 \mathrm{ng} / \mathrm{ml}$ within 2 days. This rapid decline in progesterone indicated that the hCG-induced CL were responsive to the luteolytic action of PGF-2 $\alpha$ earlier than spontaneously formed CL of similar age. Two hCG-treated heifers, one given PGF-2 $\alpha$ on Day 12 and one on Day 14, maintained progesterone between 2 and $3 \mathrm{ng} / \mathrm{ml}$ for $4-5$ days before decreasing to $<1 \mathrm{ng} / \mathrm{ml}$. This type of response has been reported in cows treated with an analogue of $\mathrm{GnRH}$, followed by an injection of 25 mg PGF- $2 \alpha 1$ or 2 days later (MacMillan et al., 1985). When PGF-2 $\alpha$ was given after the GnRH analogue, progesterone decreased in response to PGF-2 $\alpha$, but was maintained near $2 \mathrm{ng} / \mathrm{ml}$ in the presence of a palpable CL for 3-6 days, and subsequent oestrus was delayed. In the present study, heifers were not palpated after PGF- $2 \alpha$, but maintenance of elevated serum progesterone values for 4-5 days in those 2 heifers after PGF- $2 \alpha$ indicated that luteal function was not abolished. Perhaps the dose of PGF- $2 \alpha$ was not always large enough to cause complete regression of the increased luteal mass that is seen in cows treated with hCG during midcycle (Venhuizen et al., 1972; H. J. Howard \& J. H. Britt, personal observations).

Persistence of CL function and extended oestrous cycles in control heifers of the hCG-treated cycle might have been due to effects of hCG on follicular development. Although the interval from luteolysis to oestrus was extended in hCG-treated heifers, the rise in serum oestradiol before oestrus was similar among all treatment groups, suggesting that, once development of the dominant preovulatory follicle began, oestrus soon followed. Oestradiol from the dominant follicle is probably requisite for uterine PGF-2 $\alpha$ release (Thatcher et al., 1986), because it induces formation of oxytocin receptors on the endometrium, and oxytocin then causes PGF- $2 \alpha$ release by interacting with oxytocin receptors (McCracken et al., 1984). Villa-Godoy et al. (1985) demonstrated that lifespan of the CL and duration of the oestrous cycle were extended when midcycle antral follicles were destroyed by cauterization and X-irradiation. Hughes et al. (1987) also irradiated and cauterized ovarian follicles and found that not only were lifespan of the CL and oestrous cycles extended, but progesterone only decreased to $2-3 \mathrm{ng} / \mathrm{ml}$ after $15 \mathrm{mg}$ PGF- $2 \alpha$, a dose that resulted in complete luteolysis within 2 days in sham-operated controls. This suggests that a product of ovarian follicles, presumably oestradiol, may be necessary for PGF- $2 \alpha$ to cause complete luteal regression. In support of this concept, Hixon et al. (1983) showed that $200 \mu \mathrm{g}$ oestradiol benzoate given twice daily from Days 10 to 12 in combination with 7 mg PGF- $2 \alpha$ on Day 12 induced complete luteolysis in heifers, whereas neither treatment given alone induced complete luteal regression. In the present study, hCG-induced atresia of developing antral follicles might therefore have contributed to the extended CL lifespan due to a reduction of oestradiol from the ovary. In studies in this laboratory (H. J. Howard, R. G. Scott \& J. H. Britt, unpublished) we have measured concentrations of oestradiol in serum samples taken every 6 or $12 \mathrm{~h}$ from Day 10 (time of hCG) through Day 20. In conjunction with stimulated follicular development with hCG, there was an increase in 
oestradiol associated with ovulation of the midcycle follicle. After Day 12, oestradiol remained $3-4 \mathrm{pg} / \mathrm{ml}$ through Day 20 in hCG-treated animals, whereas oestradiol increased from Day 16 to 20 in normal cycles. Thatcher et al. (1989) treated cows with a GnRH analogue during midcycle and monitored follicular dynamics using real-time ultrasound. They found that while number of follicles was not affected by the GnRH analogue, there was an increase in occurrence of cloudy follicles, indicative of increased luteinization or atresia of follicles. This was attributed to stimulated secretion of LH. Thus, hCG probably has similar effects on the dynamics of follicular development. The delay from PGF- $2 \alpha$ or luteolysis to oestrus in hCG-treated heifers might therefore represent the 4-6 days required for a new wave of follicular development to occur (Sirois \& Fortune, 1988).

In conclusion, it appears that control of follicular development as well as luteal function may be important for precise regulation of reproductive cycles in cattle.

Paper No. 12436 of the Journal Series of the North Carolina Agricultural Research Service, Raleigh, N.C. 27695-7601. The use of trade names in this publication does not imply endorsement by the North Carolina Agricultural Research Service of the products named, or criticism of similar ones not mentioned. This research was supported in part by the North Carolina Dairy Foundation. We thank Vickie Hedgpeth, Donna Gallant and Robin Scott for technical assistance; James Johnson and Chris Brown for care of the experimental animals; and Dr N. R. Mason for antiserum to oestradiol.

\section{References}

Alila, H.W. \& Hansel, W. (1984) Origin of different cell types in the bovine corpus luteum as characterized by specific monoclonal antibodies. Biol. Reprod. 31, 1015-1025.

Battista, P.J., Rexroad, C.E., Jr \& Williams, W.F. (1984) Effects of progesterone administered to dairy heifers on sensitivity of corpora lutea to PGF- $2 \alpha$ and on plasma LH concentration. Theriogenology 22, 47-58.

Beal, W.E., Milvae, R.A. \& Hansel, W. (1980) Oestrous cycle length and plasma progesterone concentrations following administration of prostaglandin F-2 $\alpha$ early in the bovine oestrous cycle. J. Reprod. Fert. 59, 393-396.

Bernard, C., Valet, J.P., Beland, R. \& Lambert, R.D. (1983) Prediction of bovine ovulation by rapid radioimmunoassay for plasma LH. J. Reprod. Fert. 68, $425-430$.

Cox, N.M., Ramirez, J.L., Matamoros, I.A., Bennett, W.A. \& Britt, J.H. (1987) Influence of season on estrous and luteinizing hormone responses to estradiol benzoate in ovariectomized sows. Theriogenology 27, $395-405$.

Donaldson, L. \& Hansel, W. (1965) Histological study of bovine corpora lutea. J. Dairy Sci. 48, 905-909.

Eduvie, L.O. \& Seguin, B.E. (1982) Corpus luteum function and pregnancy rate in lactating dairy cows given human chorionic gonadotropin at middiestrus. Theriogenology 17, 415-422.

Farin, C.E., Moeller, C.L., Mayan, H., Gamboni, F., Sawyer, H.R. \& Niswender, G.D. (1988) Effect of luteinizing hormone and human chorionic gonadotropin on cell populations in the ovine corpus luteum. Biol. Reprod. 28, 413-421.

Fitz, T.A., Mayan, M.H., Sawyer, H.R. \& Niswender, G.D. (1982) Characterization of two steroidogenic cell types in the ovine corpus luteum. Biol. Reprod. 27, 703-711.

Fitz, T.A., Hoyer, P.B. \& Niswender, G.D. (1984a) Interactions of prostaglandins with subpopulations of ovine luteal cells. I. Stimulatory effects of prostaglandins E1, E2 and 12. Prostaglandins 28, 119-126.

Fitz, T.A., Mock, E.J., Mayan, M.H. \& Niswender, G.D. (1984b) Interactions of prostaglandins with subpopulations of ovine luteal cells. II. Inhibitory effects of PGF $-2 \alpha$ and protection by PGE2. Prostaglandins 28, 127-138.

Frank, R., Johnson, W.S., Turner, L.G. \& Sieck, R.F. (1983) Radioimmunoassay method for determination of estradiol (E2 $\beta)$ and estrone (E1) in cattle tissues. In Anabolics in Animal Production, pp. 393-409. Eds E. Meissonier \& J. Mitchell-Vigneron. Office International des Epizootie, Paris.

Garrett, J.E., Geisert, R.D., Zavy, M.T., Greiss, L.K., Wettemann, R.P. \& Buchanan, D.S. (1988) Effect of exogenous progesterone on prostaglandin F $2 \alpha$ release and the interestrous interval in the bovine. Prostaglandins 36, 85-96.

Hafs, H.D., Louis, T.M., Noden, P.A. \& Oxender, W.D. (1974) Control of the estrous cycle with prostaglandin F $2 \alpha$ in cattle and horses. J. Anim. Sci. 38 (Suppl. 1), 10-21.

Helmer, S.D. \& Britt, J.H. (1987) Hormone secretion and characteristics of estrous cycles after treatment of heifers with human chorionic gonadotropin or prostaglandin F2 $\alpha$ during corpus luteum formation. J. Anim. Sci. 64, 782-789.

Hixon, J.E., Pimental, C.A., Weston, P.G., Chafetz, E.P., Shanks, R.D. \& Hansel, W. (1983) A luteolytic interaction between estradiol benzoate and 
prostaglandin $\mathrm{F} 2 \alpha$ in cattle. $J$. Anim. Sci. 56, 1190-1197.

Hughes, T.L., Villa-Godoy, A., Kesner, J. \& Fogwell, R.L. (1987) Destruction of bovine ovarian follicles: Effects on the pulsatile release of luteinizing hormone and prostaglandin $\mathrm{F} 2 \alpha$-induced luteal regression. Biol. Reprod. 36, 523-529.

King, M.E., Kiracoffe, G.H., Stevenson, J.S. \& Schalles, R.R. (1982) Effect of stage of cycle on interval to estrus after PGF $2 \alpha$ in cattle. Theriogenology 18, 191-207.

Lauderdale, J.W. (1972) Effects of PGF2 $\alpha$ on pregnancy and estrous cycle of cattle. J. Anim. Sci. 35, 246, abstr.

MacMillan, K.L., Day, A.M., Taufa, V.K., Peterson, A.J. \& Pearce, M.G. (1985). Effects of an agonist of gonadotropin releasing hormone in cattle. II. Interactions with injected Prostaglandin F2 $\alpha$ and unilateral ovariectomy. Anim. Reprod. Sci. 8, 213-223.

Mason, N.R. \& March, R. (1975) Cyclic AMP in the rat ovary: effect on endogenous LH secretion. Endocr. Res. Commun. 2, 357-361.

Maurer, R.R. \& Echternkamp, S.E. (1982) Hormonal asynchrony and embryonic development. Theriogenology 17, 11-22.

McCracken, J.A., Schramm, W. \& Okulicz, W.C. (1984) Hormone receptor control of pulsatile secretion of PGF $2 \alpha$ from the ovine uterus during luteolysis and its abrogation in early pregnancy. Anim. Reprod. Sci. 7, 31-55.

Niswender, G.D., Schwall, R.H., Fitz, T.A., Farin, C.E. \& Sawyer, H.R. (1985) Regulation of luteal function in domestic ruminants: new concepts. Recent Prog. Horm. Res. 31, 101-151.

Pharriss, B.B. \& Wyngarden, L.J. (1969) The effect of prostaglandin $\mathrm{F} 2 \alpha$ on the progestagen content of ovaries from pseudopregnant rats. Proc. Soc. exp. Biol. Med. 130, 92-94.

Price, C.A. \& Webb, R. (1989) Ovarian response to hCG treatment during the oestrous cycle in heifers. $J$. Reprod. Fert. 86, 303-308.

Priedkalns, J., Weber, A.F. \& Zemjanis, R. (1968) Qualitative and quantitative morphological studies of the cells of the membrana granulosa, theca interna and corpus luteum of the bovine ovary. Z. Zellforsch. mikrosk. Anat. 85, 501-520.

Refsal, K.R. \& Seguin, B.E. (1980) Effect of stage of diestrus and number of cloprostenol (ICI 80996) injections on intervals to estrus, $\mathrm{LH}$ peak and ovulation in heifers. Theriogenology 13, 37-48.

Rowson, L.E.A., Tervitt, R. \& Brand, A. (1972) The use of prostaglandins for synchronization of oestrus in cattle. J. Reprod. Fert. 29, 145, abstr.
Schomberg, D.W., Coudert, S.P. \& Short, R.V. (1967) Effects of bovine luteinizing hormone and human chorionic gonadotrophin on the bovine corpus luteum in vivo. J. Reprod. Fert. 14, 277-285.

Scott, R.G. \& Britt, J.H. (1986) Effect of estradiol, oxytocin and PGF on progesterone secretion in cows given hCG during diestrus. J. Dairy Sci. 69 (Suppl. 1), 168, abstr.

Seguin, B.E., Oxender, W.D. \& Britt, J.H. (1977) Effect of human chorionic gonadotropin and gonadotropin-releasing hormone on corpus luteum function and estrous cycle duration in dairy heifers. $A m$. J. vet. Res. 38, 1153-1156.

Sirois, J. \& Fortune, J.E. (1988) Ovarian follicular dynamics during the estrous cycle in heifers monitored by real-time ultrasonography. Biol. Reprod. 37, 308-317.

Spector, P.C., Goodnight, J.H., Sall, J.P. \& Sarle, W.S. (1985) The GLM Procedure. In SAS User's Guide: Statistics, pp. 433-506. Eds S. P. Joyner, J. P. Sall, and A. T. Allen. SAS Institute Inc. Cary.

Stevenson, J.S., Cox, N.M. \& Britt, J.H. (1981) Role of the ovary in controlling luteinizing hormone, follicle stimulating hormone, and prolactin secretion during and after lactation in pigs. Biol. Reprod. 24, 341-343.

Stevenson, J.S., Schmidt, M.K. \& Call, E.P. (1984) Stage of estrous cycle, time of insemination, and seasonal effects on estrus and fertility of Holstein heifers after prostaglandin F2 $\alpha$. J. Dairy Sci. 67, 1798-1805.

Thatcher, W.W., Terquin, M., Thimonier, J. \& Mauleon, P. (1986) Effect of estradiol-17 $\beta$ on peripheral plasma concentration of 15-keto-13,14-dihydro-PGF2 $\alpha$ and luteolysis in cyclic cattle. Prostaglandins 31, 745-756.

Thatcher, W.W., MacMillan, K.L., Hansen, P.J. \& Drost, M. (1989) Concepts on regulation of corpus luteum function by the conceptus and ovarian follicles to improve fertility. Theriogenology 31, 149-164.

Venhuizen, E.L., Wagner, J.F. \& Tonkinson, L.V. (1972) Corpus luteum response to 6-chloro-delta-17acetoxyprogesterone and hCG in the cow. Biol. Reprod. 6, 270-276.

Villa-Godoy, A., Ireland, J.J., Wortman, J.A., Ames, N.K., Hughes, T.L. \& Fogwell, R.L. (1985) Effect of ovarian follicles on luteal regression in heifers. $J$. Anim. Sci. 60, 519-527.

Watts, T.L. \& Fuquay, J.W. (1985) Response and fertility of dairy heifers following injection with prostaglandin F2 $\alpha$ during early, middle or late diestrus. Theriogenology 23, 655-661.

Received 9 January 1990 